of activity was not shared by nonsteroidal anti-inflammatory drugs such as indomethacin.

Conclusion Our studies show that SMP-114 has remarkable protective effects on the joint of adjuvant arthritic rats and collageninduced arthritic mice. These data suggest that SMP-114 will show greater benefit in slowing joint destruction and disease progression in rheumatoid arthritis in humans.

\section{FRI0029 TREATMENT OF THERAPY-RESISTANT RHEUMATOID ARTHRITIS (RA) WITH IMMUNOADSORPTION}

${ }^{1} \mathrm{H}$ Haschkovitz, ${ }^{1} \mathrm{O}$ Warchol, ${ }^{1} \mathrm{~A}$ Dunky, ${ }^{2} \mathrm{G}$ Leitner, ${ }^{2} \mathrm{~N}$ Worel, ${ }^{2} \mathrm{P}$ Höcker. ${ }^{1}$ Department of Rheumatology, Wilhelminenspital; ${ }^{2}$ Department of Transfusion Medicine, University Hospital, Vienna, Austria

\subsection{6/annrheumdis-2001.1158}

Background Refractory RA - periods of untreatable progression. Objectives Failure to conventional therapy with DMARD`s including immunosuppressive drugs can be a major problem in patients with refractory RA. We studied especially the clinical efficacy of an additional treatment with immunoadsorption using a protein A column. Totally six patients with rheumatoid factor positive RA according to the criteria of ARA (female, mean age: 45 years (20-65), duration of disease: 4-12 years) were observed in a follow-up of 6 months.

Methods Plasma was separated by a continuous flow cell separator (A S 104, Fresenius) with venous access. Separated plasma passed down columns containing protein A sepharose (Excorim, Lund, Sweden). The application was performed every second day (number of treatments $=65$ ). Two times of patient`s total plasma volume was treated. Beside clinical parameters like morning stiffness, number of swolen and painful joints and pain scale, values of IgG, IgM and IgA, peripheral blood counts, total protein and coagulation parameters were evaluated before and after each procedure.

Results Four patients showed a significant, sustaining improvement in clinical syndroms over five months.

In two cases there was only minimal and transient success. All six patients tolerated the treatment very well. In three patients transfusion of packed red cells, in two patients also substitution of $20 \%$ human albumin was necessary in addition to IgG support.

Conclusion Protein A Immunoadsorption can be considered as a method, which sometimes improves the course of refractory RA and overcomes periods of untreatable progression.

\section{FRI0030 TREATMENT WITH ETORICOXIB (MK-0663), A COX-2 SELECTIVE INHIBITOR, RESULTED IN MAINTENANCE OF CLINICAL IMPROVEMENT IN RHEUMATOID ARTHRITIS}

${ }^{1} \mathrm{SP}$ Curtis, ${ }^{2} \mathrm{~J}$ Maldonado-Cocco, ${ }^{3} \mathrm{BR}$ Losada, ${ }^{4} \mathrm{AE}$ Gallagher, ${ }^{5} \mathrm{~J} \mathrm{Ng},{ }^{5} \mathrm{~S}$ Mukhopadhyay, ${ }^{1}$ BJ Gertz. ${ }^{1}$ Clinical Research; ${ }^{2}$ Rheumatology, Instituto de Rehabilitacion Psicofisica, Buenos Aires, Argentina; ${ }^{3}$ Prof. Rheumatology, Centro Nacional de Enfermedades Reumaticas, Caracas, Venezuela; ${ }^{4}$ Clinical Research, British Hospital of Buenos Aires, Buenos Aires, Argentina; ${ }^{5}$ Biostatistics, Merck \& Co., Rahway, USA

\subsection{6/annrheumdis-2001.1159}

Background Prostanoid synthesis is catalysed by two distinct cyclooxygenase (COX) isoforms; COX-1 (constitutive) and COX-2 (inducible). NSAIDs such as aspirin, ibuprofen and indomethacin inhibit both COX isoforms. Etoricoxib has been characterised as a COX-2 selective inhibitor with doses up to $150 \mathrm{mg}$ QD (100-fold selective in human whole blood assay).

Objectives Characterise the clinically active dose range and the longer term efficacy of etoricoxib in rheumatoid arthritis (RA).

Methods Double-blind, randomised, placebo-controlled study conducted in 54 centres worldwide in 581 RA patients. Following withdrawal of prestudy NSAIDs and demonstration of a worsening of disease activity, eligible patients were randomised to once daily oral therapy with either placebo $(n=123)$, etoricoxib $10 \mathrm{mg}(\mathrm{n}=78), 60 \mathrm{mg}(\mathrm{n}=126), 90 \mathrm{mg}(\mathrm{n}=134)$, or 120 $\mathrm{mg}(\mathrm{n}=120)$ and assessed after 2, 4 and 8 weeks.

Results Over the initial 8-week period (Part I), patients taking etoricoxib $90 \mathrm{mg}$ and $120 \mathrm{mg}$ demonstrated similar efficacy, with both treatment groups showing significant improvements compared to placebo (average change from baseline $\mathrm{p}<0.05$ ) for the primary endpoints of patient and investigator global assessment of disease activity and key secondary endpoints of patient global assessment of pain and Stanford Health Assessment Questionnaire (HAQ) Disability Index. For the patient assessment of disease activity, there was -9.41 , and $-9.15 \mathrm{~mm}$ (VAS) mean difference vs. placebo (least-squares mean difference vs. placebo, responses averaged over weeks 2 to 8 for the 90 $\mathrm{mg}$, and $120 \mathrm{mg}$ etoricoxib treatment groups, respectively). Data demonstrating that longer term efficacy was maintained (up to 52 weeks) will be presented.

Etoricoxib was generally well-tolerated during Part I. There were no statistically significant trends for patients with one or more adverse events (AEs), serious AEs, drug-related serious AEs, or discontinuations due to AEs ( $\mathrm{p}>0.05$, etoricoxib vs placebo). Safety (up to 52 weeks) was generally consistent with that observed during Part I.

Conclusion Etoricoxib 90-120 mg improved the symptoms of RA over 8 weeks and was well tolerated, with longer term efficacy data demonstrating maintenance of effect. Replicative phase III studies are ongoing to evaluate the efficacy and safety of etoricoxib in patients with RA.

\section{FRI0031 CYCLOSPORIN-A PLUS METHOTREXATE COMBINATION THERAPY IS AS SAFE AS CYCLOSPORIN-A ALONE IN PATIENTS WITH EARLY RHEUMATOID ARTHRITIS}

${ }^{1} \mathrm{AH}$ Gerards, ${ }^{2} \mathrm{RB}$ Landewé, ${ }^{1} \mathrm{AP}$ Prins, ${ }^{3} \mathrm{GA}$ Bruijn, ${ }^{2} \mathrm{HS}$ Goei The, 'BA Dijkmans. ${ }^{1}$ Rheumatology, Vrije Universiteit Medical Centre, Amsterdam; ${ }^{2}$ Rheumatology, University Hospital, Maastricht; ${ }^{3}$ Rheumatology, Medisch Centrum, Leeuwarden, The Netherlands

\subsection{6/annrheumdis-2001.1160}

Background Combination therapy with cyclosporin-A (CsA) and methotrexate (MTX) has shown to be advantageous in early RA. A major concern is still the possibility of synergistically increased toxicity.

Objectives To assess whether long-term combination therapy wit CsA and MTX results in more renal and hepatic toxicity than CsA alone.

Design A randomised double blind placebo controlled trial of 48 weeks duration.

Methods 120 patients with active RA: mean age 52 yrs, mean disease duration 3 months. Patients received CsA and MTX or CsA and placebo. MTX was started at $7.5 \mathrm{mg} / \mathrm{week}$, and was increased to $15 \mathrm{mg} / \mathrm{wk}$ after 16 weeks. CsA was started at 2.5 $\mathrm{mg} / \mathrm{kg} / \mathrm{day}$, and was increased to a maximum of $5 \mathrm{mg} / \mathrm{kg} /$ day. Additionally, all patients used folic acid $1 \mathrm{mg} / \mathrm{d}$. Patients who did not have an ACR 20 response at week 24 were withdrawn. 